\title{
Semantic classification of phraseological verbs in publicistic discourse of economic orientation
}

\section{Семантическая классификация фразеологических глаголов публицистического дискурса экономической направленности}

Received: January 19, 2021

\begin{abstract}
The article examines the role of phrasal verbs in prama-semantic organisation of publicistic discourse. The relevance of this research is explained by the growing interest of linguists in the problems of using phrasal verbs in different types of discourse, as well as the poorly studied issue of phrasal verbs at the junction of economic and publicistic discourse and their pragmatic potential. The objective of he work is to demonstrate the connection between the language and the currect economic realia which constitutes the flexible nature of pragmasemantic system of discourse.

The research relies on functional-pragmatic method and component analysis. The method of continuous sampling (articles on the topic of the impact of coronavirus on the economy of different countries) was used to select the material.

On the basis of materials taken from Englishlanguage newspapers on the topic of the coronavirus impact on the economy of European countries the semantic classification of phrasal verbs was carried out, the results of which shown that the most frequent semes are «slowing down», «improvement», «novelty», «measures / actions», «refusal».

The authors conclude that the semantic classification forms the basis of communicative strategies for creating an image of various entities or people, strategies for forming a public opinion, and strategies for uniting the society. In the pragmatic system of publicistic discourse phrasal verbs are particular speech means involved in the implementation of the general
\end{abstract}

Accepted: February 22, 2021

Written by:

Alexandra V. Radyuk ${ }^{38}$

https://orcid.org/0000-0002-2818-0619

Antonina V. Kozubenko ${ }^{39}$

https://orcid.org/0000-0002-1844-6794

\begin{abstract}
Аннотация
В данной статье рассматривается роль фразовых глаголов в прагма-семантической организации публицистического дискурса. Актуальность данного исследования обусловлена возрастающим интересом лингвистов к проблемам употребления фразовых глаголов в различных типах дискурса, а также малоизученностью проблемы фразовых глаголов на стыке экономического и публицистического дискурса и их прагматического потенциала. Цель данного исследования - показать взаимосвязь между языком и текущими экономическими реалиями, которая определяет гибкий характер прагма-
\end{abstract} семантической системы дискурса.

В основе исследования лежит функционально-прагматический метод и метод компонентного анализа. Также для отбора материала был использован метод сплошной выборки (статьи на тему влияния коронавируса на экономику разных стран).

На основе материалов англоязычных газет на тему влияния коронавируса на экономику европейских стран была проведена семантическая классификация фразовых глаголов, результаты которой показали, что наиболее частыми семами являются «замедление», «улучшение», «новизна», «меры / действия», «отказ».

Авторы приходят к выводу, что семантическая классификация лежит в основе коммуникативных стратегий создания образа различных организаций или людей, стратегий формирования

\footnotetext{
${ }^{38}$ CSc in Philology, Associate Professor of Foreign Languages Department, Faculty of Economics, RUDN University, Moscow, Russia.

${ }^{39}$ MA student, RUDN University, Moscow, Russia.
} 
communicative strategies. They are indicative of national and cultural self-identitication, the striving for economic growth and social unity in crisis conditions.

Key Words: functional linguistics, publicistic discourse, phraseological units, phrasal verbs, pragmatics, semantic classification. общественного мнения и объединения общества. В прагматической системе публицистического дискурса фразовые глаголы являются частными речевыми средствами, участвующими в реализации общих коммуникативных стратегий. Они свидетельствуют о национальнокультурном самоопределении, стремлении к экономическому росту и социальному единению в условиях кризиса.

Ключевые слова: функциональная лингвистика, публицистический дискурс, фразеологические единицы, фразеологические глаголы, прагматика, семантическая классификация.

\section{Introduction}

The discourse of the modern press represents a set of speech works united around a number of communicative events. Choosing for consideration such a sphere of public life as the economy, one takes into account its dynamics and its relationship with current business events in the world and in individual countries. Global events such as the COVID-19 pandemic affect a wide variety of economic processes, however, putting together a picture of the "crisis" discourse, we can observe clusters of meanings, which appear due to:

- changes in the well-being of individuals and vulnerable segments of the population;

- negative impact of lockdown on the work of small and medium-sized businesses;

- actions taken by national governments to support individuals and businesses;

- $\quad$ rising unemployment;

- development of e-commerce and others.

In addition to these semantic clusters in the discourse associated with the above-mentioned topics, a set of means of speech expression is formed, which together perform the function of informing, creating a positive or negative image and the function of forming public consciousness (Radyuk, Ivanova, Badmatsyrenova, \& Makukha, 2019). Phraseological units in general and phrasal verbs in particular are one of the speech means of the lexical level of the language, aimed at the implementation of these functions.

Particular interest in the study of phraseological units is due to the fact that they are frequently used in the press, the main functions of which are to inform the audience about events taking place in a particular area, as well as to influence the reader, involving him in the understanding of the events of the business, economic, cultural and political agenda. However, despite the fact that phraseological units often become the subject of linguistic research, in connection with which a separate linguistic discipline - phraseology appeared in the 40 s of the XX century, not enough attention was paid to the semantic analysis of phrasal verbs in the texts of the economic discourse of the mass media.

Thus, the purpose of this article is to consider phrasal verbs as part of the phraseological system of the English language, to analyze their use in the texts of the English-language mass media discourse on the impact of coronavirus on the economy of European countries and to identify their main semantic characteristics and functions.

The relevance is determined by the fact that phrasal verbs are an integral and very significant part of the English language system and their analysis in the texts of the economic discourse of the mass media can serve as a basis for further research in related linguistic disciplines, such as lexicology, discourse theory, cognitive linguistics, sociolinguistics, and others.

The novelty of the scientific work lies in an attempt to determine the pragmatic and semantic potential of phrasal verbs in the texts of the economic discourse of the mass media.

\section{Theoretical framework}

The term phrasal (phraseological) verb was first introduced by L. P. Smith, a British essayist and critic, who defined this concept as a combination of verbs with postpositions. In his work, the 
scientist wrote that these units "not only represent one of the remarkable properties of the English language, but also form a huge number of idiomatic anomalies - phraseological units whose meaning does not follow from the meaning of their constituent elements» (Smith, 1959 , p.10). However, the question of which of the categories of phraseological units of the English language phrasal verbs can be attributed to is still open, due to the fact that scientists define and classify phraseological units in different ways. So, V. V. Vinogradov classifies phraseological units according to their semantic principle and distinguishes phraseological fusions - non-motivated units, the meaning of which cannot be deduced from the meaning of the components that make them up, phraseological unities - motivated through the image expressed in the whole construction, through the metaphors on which they are based, and phraseological combinations - motivated units, one of the components of which is used in its direct meaning and helps to determine the meaning of the whole phraseological unit (Vinogradov, 1977). A.I. Smirnitsky's approach is based on the functional component and the linguist distinguishes phraseological units (neutral, in which there is no metaphorical subtext) and idioms (metaphorical and stylistically colored) (Smirnitsky, 1998). In the classification of N. N. Amosova, phraseological units differ depending on the context and are divided into phrasemes - one of the components of which is stable, and the second is determined by the context, and idioms characterized by idiomaticity, that is, the meaning is created by the whole group and not by a mere combination of the meanings of its components (Amosova, 2017). Classification of A.V. Kunin is based on the communicative component and in this case phraseological units are divided into nominative, nominative-communicative, interjectional, communicative (Kunin, 1996).

Thus, it can be noted that in some classifications phrasal verbs can be attributed to several categories of phraseological units at once, while in others it is difficult to define them as a subtype of phraseological units.

In this article, phrasal verbs will be defined as units in which the postposition partially or completely loses its original meaning and modifies the lexical meaning of the verb, depending on the context of its use. It should also be noted that the meanings of phrasal verbs are often polysemantic, so the same phrasal verb in its different detonations can act as a completely idiomatic formation, or as a unit that partially retains the original meaning of one of its components (for example, the verb to fall down has several meanings - 1) to fall on the ground, 2) to prostrate, to bow, 3) to fail, which is a colloquial variant).

In general, among the main criteria characterizing phrasal verbs, the following can be noted:

- acquisition by a verb with a postposition of a meaning different from a verb without a postposition;

- $\quad$ the ability to replace a phrasal verb with a multi-lexeme verb or a phrase, which indicates its semantic unity;

- possession of an idiomatic property, that is, the inability to distinguish the meaning from separately taken elements;

- the location of the postposition before and after the noun used with the given verb, which determines the semantic load of the phrasal verb (Povey, 1990).

Due to the fact that phrasal verbs make up a huge layer of English vocabulary and largely ensure the success of communication, and therefore are of great interest to linguistics and phraseology in particular, scientists have made attempts to classify them based on different criteria in order to determine the essence of this linguistic phenomenon more accurately.

So, one of the criteria is the motivation of phrasal verbs, and here scientists distinguish three types:

1. non-motivated, the value of which cannot be determined from the individual units that make them up (get across - 1) to irritate, 2) to make someone understand or believe something);

2. partially motivated, in which the verb determines the main direction of the meaning of the entire phraseological unit, however, often this meaning is also very difficult to identify from individual components (to look down - to think that you are better than somebody);

3. the third type - motivated phrasal verbs - is rather controversial, since it opposes the very concept of idiomaticity, which most scientists define as the main criterion for phraseological units. In this case, the meaning of the entire phrasal verb can be guessed from the values of all its 
components (come back - to return to a place).

In addition, there is a structural and grammatical classification, according to which phrasal verbs are divided into transitive and intransitive. Transitive verbs are verbs that require a direct object after themselves, for example, to call for someone - to go to a place in order to collect someone. Sometimes a phrasal verb has two additions: She asked Michael for help.

Intransitive verbs do not require an object after themselves, for example, to grow up - to gradually become an adult.

However, even here there is a difficulty, since the same phrasal verb in different meanings can be both transitive and intransitive. - He took off the tie when he came home. The plane will take off in ten minutes.

Another classification is that of the Swiss linguist Sh. Bally, who considered phrasal verbs on the principle of their separability. Non-separable phrasal verbs include all intransitive verbs and some transitive verbs. Their peculiarity is that the object must come exclusively after them, for example, «I had to run to catch up with her».

In separable phrasal verbs, the object can stand between the verb and the postposition - «We tried to get our point across, but he just wouldn't listen». But if the object is expressed by a pronoun, then it must come before the postposition.

But once again, there is no clear rule by which one can determine whether a particular phrasal verb is separable or not. In many cases, to understand this, it is necessary to turn to a dictionary for help.

In addition to the above classifications, it should be noted that phrasal verbs are also considered in relation to their semantics. However, often when considering the semantic properties of these lexical units, the analysis of the semantics of the postposition is taken as a basis. Thus, here are phrasal verbs where the postposition expresses the spatial meaning (come out - to appear), the derived meaning, in which there is the relationship with the primary meaning of the verb (pick up - to lift something or someone up), where the postposition emphasizes the semantic significance of the verb (pull through - to stay alive after you have been very ill or badly injured, or to help someone do this), in which the postposition bears no separate semantic significance and represents a single indivisible meaning is with the verb (fall out - to quarrel), and also verbs in which the postposition brings lexically specific hue (eat up - to eat all of something, break out - if something unpleasant such as a fire, fight, or war breaks out, it starts to happen, etc.).

A.R. Zabolotskaya (2015) called such verbs compositional, including combinations with a directional postposition that retains its spatial meaning and an aspectual postposition that gives the verb the completeness of the action, and noncompositional, having signs of idiomatic combinations, the meaning of which cannot be distinguished from individual elements.

However, in the course of this study, the classification proposed by T. B. Pivonenkova (2013) is of interest, who, when analyzing the semantics of phrasal verbs, decided to consider not their separate units, but their totality. Thus, nine groups of verbs were identified, united by their semantics:

1. Phrasal verbs denoting actions that characterize success / failure in business. (breeze through - to achieve something very easily).

2. Phrasal verbs related to the state of a person or to its change (get across-to irritate).

3. Phrasal verbs that express relationships between people (split up-to end the relationship).

4. Phrasal verbs that characterize the behavior of a person in society, the attitude to the events taking place (thrust something upon somebody - if something is thrust upon you, you are forced to accept it even if you do not want it).

5. Phrasal verbs that express the beginning or end of an action (set about - to start something).

6. Phrasal verbs that express a person's involvement in an action (be glued to something - to look at something with all your attention).

7. Phrasal verbs that express the stability of the object's state (roll in something - to drown in something).

8. Phrasal verbs that describe the thought processes associated with receiving and transmitting information (get across - to express your thoughts clearly).

9. Phrasal verbs that express the cessation or beginning of movement (burst in - to interrupt someone or something by entering a room, in a way that embarrasses you or other people). 


\section{Methodology}

Economic discourse is considered to be a type of institutional discourse that is why its existence is predetermined by the choice of a set of verbal means in professional contexts. The choice is guided by the major and minor aims set by the discourse producer which makes economic discourse an object of functional linguistics and discourse analysis (Malyuga, Tomalin, 2014; Malyuga, Orlova, 2016). Rhetorical and functional efficiency of discourse is on y ща the crucial issues oa discourse analysis. It studies how cultural, social and institutional connections affect the language (Aleksandrova, Mendzheritskaya \& Malakhova, 2017; Baranova \& Kriakina, 2020). Discourse analysis studies interpersonal communication and the way languages influences national, geographic, political identity (Schiffrin, Tannen \& Hamilton, 2005). In the framework of the present study, we aim to investigate a blend of publicistic and economic discourse - press materials connected with the topic of coronavirus crisis in the economies of the world and measures implemented by the states to overcome it. In this regard, the research material constitutes a system of discourse products (articles, speeches, interviews, talks, meetings transcripts) which create a pragma-sematic space of meanings and logical-semantic relations between them peculiar to this institutional sphere (see Arutyunova, 1990, Karasik, 2002, Malyuga, McCarthy, 2018, Radyuk, Banshchikova \& Lisyutina, 2017, Ponomarenko, 2016, Ponomarenko, 2018).

In real communication one rarely observes pure registers of speech. More often, registers and types of discourses intersect and contain features peculiar to several types depending on the topic, publishing medium, amount of people involved in discourse.

Publicistic discourse represents a set of speech works related to certain ideological and communicative situations connected with the events of the world and existing in a certain time space (Krivtsova \& Kucheryavenko, 2019). The basic communicative intentions of authors of publicistic discourse are to inform and to influence the audience, to form public opinion. Some of the aspects that define it are simplicity of presentation, brevity and expressiveness.

Economic discourse in media is a special language united by the sphere of institutional activities connected with economic processes. It is an embodiment of a system of economic knowledge represented by a set of speech means depicting the realia of the economy and addressed to an abstract addressee.

The work has been carried out by method of component analysis (singling out the typical semes) and functional-pragmatic analysis.

Verbal expression of people, objects, values and beliefs is often composed in a way that the listener / reader can identify the author with a specific profession, social group or other entity. Putting speech into context makes us consider such phenomenon as discourse. J.P. Gee divides the tools of discourse analysis into the following spheres (Gee, 2011, p.37):

a. Discourses: how humans build activities and identities through other aspects beside language.

b. Social languages: how humans use different styles or language variations for different purposes to recognise different identities in different settings.

c. Conversations: how humans talk or write something that does not only relate to someone else's words but also relates to themes, debates, or motives that have been the focus of much talk and writing in some social group.

d. Intertextuality: the words of a human relate to other texts that someone has written or said (Gee, 2011, p. 28-29).

Functional-pragmatic analysis allows to take into account the role of such extralinguistic components as the conditions of speech production, the speaker's belonging to a particular social group, the position held by the speaker, political views, etc. (Malyuga \& Orlova, 2017). This method involves identifying the communicative goal of the utterance, determining speech means for achieving this goal, identification of communicative strategies (global intention) and communicative tactics (means of its implementation), associated with the concept of crisis coronavirus discourse.

Also, in accordance with the views of functionalists, the discourse is not a static entity, but an open nonlinear self-regulating system, which means that the functional-pragmatic organization of the discourse is systemic (Radyuk, 2016, Ponomarenko, 2018). The communicative purpose of the utterance serves as a functional attractor - the sphere of attraction of the pragmatic potential of multilevel means of speech expression. Pragma-semantic 
connections between the utterances, arranged in a certain sequence, serve as order parameters and control the functioning of the system.

\section{Results and discussion}

Based on this classification, the analysis of phrasal verbs in journalistic texts of economic orientation was carried out and an attempt was made to develop its own classification of phrasal verbs based on their semantic component.

First of all, it is necessary to note that phrasal verbs actually make up a large layer of the English language, since they were found in each of the analyzed articles and the frequency of their use was, in general, 2-3 phrasal verbs per article. Thus, for the analysis by the method of controlled selection (articles on the topic of the impact of coronavirus on the economy of different countries), 100 were selected, in which phrasal verbs were present. At the same time, the selected verbs were partially motivated or unmotivated (non-compositional) verbs (in accordance with the classification of A. R. Zabolotskaya (2015), there are distinguished compositional verbs that include combinations with a postposition of direction that retains its spatial meaning, as in «to go away - to escape» and non - compositional phrasal verbs that have signs of idiomatic combinations, since it is impossible to distinguish the meaning of the entire phrasal verb from its components- «to fall out - to quarrel»).

When trying to classify the verbs encountered on the semantic principle, nine groups were identified, among which:

1. The first and most common were the verbs with the seme of reduction, slowing or cessation of any process: slow down - to become less active or busy than you usually are, cut off - to disconnect, run out - to use all of something and not have any more left, hold up - to delay someone or something, fall behind - to go more slowly than other people so that they gradually move further ahead of you, hold back to make someone or something stop moving forward, go down to become lower in level, amount etc., peel back - to lessen, ease off - to decrease or get less, keep down - to reduce, cut back - to reduce costs, switch off - to stop, close down - to stop operating permanently, get out - to leave, fall over - to go bankrupt, hunker down - to stay in a place or position for a long time, usually in order to achieve something or for protection, etc.
The US has regained about half of the jobs lost, but economists and businesses have been pushing Congress to approve further economic relief, as programs expired and money ran out, prompting recovery to slow down.

2. The second group includes phrasal verbs denoting refusal: turn down-to to refuse an offer or request, rule out - to make it impossible for something to happen, give up - to stop doing something, especially something that you do regularly, talk out of - to persuade someone not to do something, step back - to retreat, bat away - to avoid, dismiss, or disregard some comment or question, etc.

The scientists who developed the vaccine have said publicly that the EU originally turned down an offer for a further order.

3. The third group includes the verbs denoting positive changes, such as pick up - to gain momentum, kick in - to start acting, double down - to double a bet, clear up - to go away, changing into a better condition, wake up to start to understand that a situation or problem exists, settle in - to become familiar with somewhere new and to feel comfortable and happy there, hold up - support, roll outto implement, go up - to move higher, rise, or increase, and bounce back - to get back to normal, play out - to happens and to develop, catch up - to reach the same quality or standard as someone or something else, go around - to be enough for everyone, keep up - to be able to understand or deal with something that is happening or changing very fast, step up - to take action when there is a need or opportunity for it, etc.

After President Emmanuel Macron communicated his anger at the delays at the weekend, the pace is picking up.

4. The fourth group consists of verbs that denote the distance between something: take away - to remove something, especially without permission, take hold - to spread: miss out - to not include someone or something, hold up - to delay, shut down - to stop operating, either permanently or for a short time, give away - to give something to someone without asking for any money, break down - to change or remove something that prevents people from working together and having a successful relationship with each other, put off - to decide or arrange to delay an event or 
activity until a later time or date, step back to stop being involved in something, to retreat, pass on - to transmit, come out - to remove from a place, couple with - to combine with, add up - to match, to seem reasonable or likely.

As the new coronavirus variant takes hold across the whole of the UK, we are hearing widespread reports of rapidly rising absences in the food supply chain," he said.

5. The fifth group includes verbs that have the seme of increase: go up - to increase in price, amount, level etc, pick up - to increase, ramp up - to increase an activity, get up - to increase, to become stronger.

By Friday, the figure had gone up to 45,500 - still so small as to be statistically meaningless.

6. The following group includes phrasal verbs with the seme of the beginning of something new: roll out - to make a new product, service, or system available for the first time, fill out - to become larger, set up - to establish, to arrange, kick in - to start acting, come up - to appear, to become available, show up - to appear or be seen, pick up - to start anew, carry out-to carry out, get off - to start, turn up - to appear.

There is already a nationwide network of independent laboratories which have become testing sites, though others have been set up by town halls.

7. The seventh group includes words that have the seme of overcoming - go out - to end, get out - to succeed in doing something, especially when this is very difficult, go around - to be enough for everyone, make through - to experience, tide over - to help someone through a difficult period, especially by lending them money, carry on - to continue, work out - to get better or to get solved, cling on - to continue trying to stay in power, in business etc.

A survey of the trade body's members revealed that $80 \%$ of businesses did not have enough cash to make it through to April.

8. The eighth group consists of the verbs related to payments - pay back - to repay an amount of money that was borrowed, make up - to compensate, get back - to return, pay out-to give or disburse money to someone for a service or as a fee, sell off - to dispose of something by selling it, especially at reduced prices, in order to make money quickly, cut back-to reduce expenses.

Eluned Morgan, the Minister for Mental Health, Wellbeing and the Welsh Language, said about $£ 20 m$ had already been paid out, adding that the scheme offered more generous payments than the one in England.

9. Finally, the ninth group includes verbs that denote human behavior or interactions between people: take on - to decide to do something even though it was not one's responsibility, call for - to require something, look for - to search for someone or something, point out - to bring attention to someone or something, sign off - to approve, pore over - to examine, study, or read with intense, careful attention, held up - to set an example.

The UK meat industry has called for the early vaccination of workers to keep food supplies running smoothly during the coronavirus crisis.

\section{Conclusions}

It should be noted that in some phrasal verbs, the meaning varied depending on the context in which they were used, and therefore the same verb could fall into different semantic groups. In this regard, it is very difficult to clearly define the boundaries of a particular semantic group, since in different contexts, meanings can have different shades.

According to the research, the system of phrasal verbs is built in the publicistic discourse around such concepts as slowing down, improvement, novelty, measures / actions, refusal. It should be noted that such a semantic repertoire indicates communicative strategies for creating an image (of the state/government/political figures), strategies for forming public opinion, and strategies for uniting society. Phrasal verbs are particular speech means involved in the implementation of communicative tactics. These strategies are an indicator of national and cultural self-identification, the striving for economic growth and social unity in crisis conditions.

In general, in the material selected for analysis, due to the fact that the latest news in the field of economics is closely related to the pandemic and coronavirus, in journalistic texts of an economic orientation, phrasal verbs with the seme of 
termination or slowing down prevail (17 verbs), the second most frequent seme is of positive changes ( 15 verbs), the third one is the verbs denoting distance (13 verbs), the fourth is the beginning of something new (10), the fifth is overcoming difficulties that arise (8), the sixth is the behavior or actions of a person (7), and the last ones are the semes of rejection of something and verbs related to payments (6).

Thus, as a result of the analysis, a semantic classification of phrasal verbs in the texts of the English-language mass media discourse on the impact of the coronavirus on the economies of European countries was carried out and the areas of the most frequent use of phrasal verbs were identified.

The classification allows us to draw conclusions about the functioning of discourse as an ongoing process, inextricably linked with the realities of social and economic life of people. The system of phrasal verbs that concentrate around certain semantic fields is a dynamic formation that interacts with the external environment extralinguistic factors of actualization of publicistic discourse. The designated semantic fields were formed due to the adaptation of the pragma-semantic system of discourse to new external factors. The chosen object of research phrasal verbs - is one of the aspects of a dynamic, open and nonlinear system of discourse.

\section{Acknowledgment}

This paper has been supported by the RUDN University Strategic Academic Leadership Program

\section{Bibliographic references}

Aleksandrova, O. V., Mendzheritskaya, E. O., \& Malakhova, V. L. (2017). Dynamic changes in modern English discourse. Training, Language and Culture, 1(1), 92-106. Doi: https://doi.org/10.29366/2017tlc.1.1.6

Amosova, N.N. (2017) Fundamentals of English phraseology. Moscow: Librocom

Arutyunova, N.D. (1990). Discourse. In Linguistic Encyclopedic Dictionary (pp. 136-137). Moscow: Sovetskaia Entsiklopediia.

Baranova, L. L., \& Kriakina, N. L. (2020). 'Safe' political discourse: Linguo-cultural and pragmalinguistic perspectives. Training, Language and Culture, 4(3), 31-42. Doi: https://doi.org/10.22363/2521-442X-2020-4-3$31-42$
Gee, J.P. (2011). An introduction to discourse analysis theory and method. UK: Routledge.

Karasik, V.I. (2002). Language circle: personality, concepts, discourse. Volgograd: Peremena.

Krivtsova, T. F., \& Kucheryavenko, V. V. (2019). The linguistic aspect behind the changing attitudes towards 'globalisation' and 'deglobalisation' of economic processes (a case study of the German print media). Training, Language and Culture, 3(3), 56-69. doi: https://doi.org/10.29366/2019tlc.3.3.4

Kunin, A.V. (1996) Course of Modern English Phraseology. Moscow: Vysshaya shkola Publ.

Malyuga, E., \& McCarthy, M. (2018). English and Russian vague category markers in business discourse: Linguistic identity aspects. Journal of Pragmatics, 135, 39-52.

DOI: https://doi.org/10.1016/j.pragma.2018.07. 011

Malyuga, E., \& Tomalin, B. (2014). English professional jargon in economic discourse. Journal of Language and Literature, 5(4), 172-180. Doi: 10.7813/j11.2014/5-4/38

Malyuga, E.N., \& Orlova, S.N. (2017). Linguistic pragmatics of intercultural professional and business communication. Springer.

Malyuga, E.N., \& Orlova, S.N. (2016). Teaching Professional English Terminology to Students of Economic Universities. In 8th International Conference on Education and New Learning Technologies (EDULEARN) (pp. 7236-7241). Barcelona, SPAIN.

Pivonenkova, T. (2013). Semantic classification of the phrasal verbs with figurative potential. Bulletin of the Moscow State Regional University. Series: Linguistics. No. 2. Retrieved from:

https://cyberleninka.ru/article/n/semanticheskay a-klassifikatsiya-frazovyh-glagolov-s-

obraznym-potentsialom (accessed 11 January, 2021)

Ponomarenko, E.V. (2018). Factors of Business English functional efficiency. In SGEM International Multidisciplinary Scientific Conference on Social sciences and Arts. Vol. 5. № 3.6. (pp. 209-216). Vienna: STEF technology.

Ponomarenko, E.V. (2016). Functional properties of English discourse in terms of linguosynergetics. In 3rd International Multidisciplinary Scientific Conference on Social Sciences and Arts SGEM 2016 Proceedings, Book 1, Vol. 3, (pp. 355-362). Bulgaria, Albena. DOI: 10.5593/sgemsocial2016/B13/S03.042 
Povey, J. (1990). Phrasal verbs and how to use them. Moscow: Vysshaya shkola Publ.

Radyuk, A.V. (2016). Criteria of English Business Discourse Effectiveness in View of Dynamic and Systemic Approach. Vestnik Volgogradskogo Gosudarstvennogo Universiteta - Seriya 2 -Yazykoznanie, 15 (3), 196-205.

Radyuk, A., Banshchikova, M., \& Lisyutina, O. (2017). Goal setting strategy in economic discourse: prosodic peculiarities and linguodidactic aspects. In Chova, L.G.; Martinez, A.L.; Torres, I.C. (Eds.) 9th International Conference on Education and New Learning Technologies (EDULEARN17) (pp. 876-881). Barcelona, Spain.

Radyuk, A.V., Ivanova, M.V., Badmatsyrenova, D. A., \& Makukha, V.S. (2019). PragmaSemantic Relations in the Structure of a Business Microblog. International Journal of English Linguistics, 9(60), 392-403.
Schiffrin, D., Tannen, D., \& Hamilton, H.E. (Eds.). (2005). The Handbook of Discourse Analysis. Blackwell Publishers DOI: https://doi.org/10.1002/9780470753460

Smith, L.P. (1959). English idioms (From words and idioms, studies in the English language). London: RuMoRGB.

Smirnitsky, A.I. (1998) Lexicology of the English language. Moscow: Moscow state University Vinogradov V. V. (1977) Selected works. Lexicology and lexicography. Moscow, Nauka. Zabolotskaya, A.R. (2015). Mastering structural, grammatical and semantical features of phrasal verbs by students of non-linguistic specialities. Philology and Culture, № 4 (42), pp 274-278 Retrieved from: https://cyberleninka.ru/article/n/izucheniestrukturno-semanticheskih-i-grammaticheskihosobennostey-frazovyh-glagolov-angliyskogoyazyka-studentami-neyazykovyh (accessed 12 January, 2021) 